\title{
MUHAMMADIYAH DI TENGAH ISU DUNIA ISLAM KONTEMPORER: REFLEKSI UNTUK INTERNASIONALISASI
}

\section{- Marpuji Ali}

\author{
Universitas Muhammadiyah Surakarta (UMS), Indonesia
}

Email: marpujiali@yahoo.com

\section{Abstrak}

Tulisan ini membahas tentang bagaimana Muhammadiyah berhadapan dengan isu-isu dunia Islam kontemporer, khususnya menyangkut masalah ketertinggalan umat Islam dan kemiskinan. Oleh karena kemiskinan yang mendera, - baik itu oleh sebab-sebab struktural dan kultural - maka umat Islam mengalami ketertinggalan di dunia global. Demikian pula dengan aspek pendidikan yang disinyalir akan mampu meningkatkan kualitas hidup umat, juga mengalami jalan buntu tatkala dihadapkan dengan persoalan ekonomi. Banyak orang miskin yang tidak memiliki akses pada lembaga-lembaga pendidikan Islam yang memiliki kualitas terbaik. Dalam rangka memikirkan itu semua, sebenarnya Muhammadiyah memiliki modal nilai-nilai etis kebajikan yang bersifat solutif, tatkala dihadapkan dengan persoalan-persoalan tersebut. Pemikiran mengenai moderatisme Islam adalah salah satu dari nilai yang sangat potensial untuk menyatukan antara iman dan amal saleh manusia. Dengan demikian, persyarikatan ini tidak perlu terjebak dalam dua arus pemikiran ekstrim yang justru kontraproduktif dengan nilai-nilai Islam itu sendiri, seperti misalnya fundamentalisme atau liberalisme. Melalui kesinambungan antara iman dan amal ini, Muhammadiyah bisa menjadi pioner dalam kerja-kerja kemanusiaan dan keadilan sosial. Nilai-nilai kebajikan itulah yang layak didakwahkan kepada publik internasional.

Kata Kunci: Muhammadiyah, moderatisme Islam, kemiskinan, pendidikan Islam, internasionalisasi 


\section{Pendahuluan}

Sejak hadirnya bangsa Barat ke ranah kehidupan umat Islam, mulai dari bentuk penjajahan wilayah, dominasi ilmu pengetahuan dan budaya, hingga kekuasaan politik, umat Islam senantiasa berhadapan dengan sejumlah dilema. Salah satu dilema itu adalah antara mengikuti arus perubahan yang dikendalikan melalui "kekuasaan" Barat itu di satu sisi, dan mempertahankan identitasidentitas sebagai umat Islam di sisi yang lain. Sejarah telah mencatat bahwa pasca keruntuhan kekuasaan Islam di Cordova, Granada dan Andalusia, ${ }^{1}$ kendali yang dipegang oleh umat Islam atas peradaban dunia mulai melemah, untuk kemudian secara pasti menyurut dan beralih ke tangan Barat. Peralihan kendali peradaban ini lalu menjadikan umat Islam sebagai kelompok yang lemah dan tercerai berai di hadapan kekuasaan Barat yang mulai bangkit dan mengalami kematangan.

Maka, Barat adalah cerita dua sisi bagi umat Islam. Barat adalah inspirasi dan model, tetapi sekaligus saingan dan ancaman. Narasi tentang pembaruan di seantero dunia Islam, di samping disebabkan oleh dorongan internal berupa kejumudan dalam diri umat Islam, ${ }^{2}$ pada saat yang sama juga terdorong oleh interaksi Islam dan Barat di permulaan era yang lalu dikenal sebagai era modern. Maka aksi-aksi pembaruan baik yang dilakukan oleh penguasa politik Islam seperti Sultan Salim II atau Sultan Abdul Majid pada era akhir kekuasaan Turki Usmani, ataupun pembaruan yang diprakarsai oleh sejumlah pemikir seperti Ibn Taymiyyah, Wali-Allah al-Dihlawi di India, Utsman bin Fodio di Afrika, Muhammad Abduh dan Muhammad Rasyid Ridha di Mesir, Syukri al-Alusi di Baghdad, hingga Ahmad Dahlan di Indonesia, semua merupakan respons atas perpaduan dua dorongan internal berupa kejumudan pemikiran umat Islam sekaligus penetrasi atas modernisme Barat ke dalam dunia Islam. ${ }^{3}$

Dinamika seperti ini terus berlanjut hingga kini. Problem kontemporer yang dihadapi oleh umat Islam saat ini tak kalah peliknya. Dari problem kemiskinan dan ketertinggalan, pecah-belah umat oleh perbedaan sikap politik dan perbedaan

Lihat Raghib al-Surjani, Qissatu al-Andalusi: Min al-Fathi ila al-Suquth (Mesir: Mu'assasah al-Iqra' li alTansyir wa al-Tauzi', 2011).

2 Karya pengantar yang cukup representatif untuk memetakan gerakan dan pemikiran seputar pembaruan dalam dunia Islam adalah Harun Nasution, Pembaharuan dalam Islam: Sejarah Gerakan dan Pemikiran (Jakarta: Penerbit Bulan Bintang, 1975).

3 Silahkan merujuk ke Suha Taji Farouki dan Basheer M Nafi, Islamic Thought in the Twentieth Century (London and New York: I.B.Tauris, 2004), terutama bagian pendahuluan. 
interpretasi agama, hingga praktik-praktik radikalisme keagamaan yang secara serampangan sering dilekatkan kepada umat Islam. Maka, tulisan ini bermaksud memetakan sebagian kecil dari isu-isu kontemporer yang dihadapi umat Islam dan menentukan posisi serta peran apa yang bisa dimainkan Muhammadiyah di tengah pergulatan berbagai isu kontemporer dunia Islam. Karena luas dan kompleksnya isu-isu kontemporer dalam dunia Islam ini, maka tulisan ini akan dibatasi pada pembahasan dan analisis atas dua persoalan saja, yakni tentang kemiskinan dan ketertinggalan umat Islam, serta radikalisme agama. Aktivitas diskursif ini, dimaksudkan sebagai refleksi intelektual untuk menyelesaikan masalah umat, sekaligus untuk internasionalisasi nilai-nilai kebajikan Muhammadiyah.

\section{Kemiskinan dan Ketertinggalan Umat Islam}

Salah satu problem utama yang dihadapi oleh dunia Islam adalah ketertinggalan dan kemiskinan. Kedua persoalan ini sebenarnya bersifat kausal atau jalin menjalin satu sama lain. Sebagai titik tolak untuk memahami persoalan ini, data statistik tentang peringkat Human Development Index (HDI) negaranegara Muslim bisa dihadirkan. HDI yang dirilis oleh United Nation Development Programme (UNDP) membagi peringkat sumberdaya manusia negara-negara dunia ke dalam peringkat sumberdaya manusia sangat tinggi (very high human development), sumberdaya manusia tinggi (high human development), sumberdaya manusia menengah (medium human development), dan sumberdaya manusia rendah (low human development). Menurut data ini, beberapa negara Muslim berada pada kategori very high human development pada 2013, seperti Brunei Darussalam (30), Qatar (31), Saudi Arabia (34), Uni Emirat Arab (40), Bahrain (44), dan Kuwait (46). Pada kategori high human development terdapat Libya dan Oman (masingmasing di peringkat 55 dan 56), disusul Malaysia (62), Turki (69), Iran (75), Jordan (77), Tunisia (90), Algeria (93). Pada peringkat medium human development terdapat Palestina (107), Indonesia (108), Mesir (110), Iraq (120), Bangladesh (142). Sementara pada peringkat low human development terdapat Pakistan (146), Yaman (154), Syria dan Sudan (166), (Afghanistan (169).

Data ini menunjukkan tingkat sumberdaya manusia yang bervariasi antara satu negara Muslim dengan negara Muslim lainnya. Memang benar, sejumlah negara Muslim telah mampu menempatkan diri sejajar dengan negara-negara lain di peringkat sangat tinggi. Namun demikian, pada saat yang sama, sejumlah negara Muslim lainnya ternyata memiliki tingkat kemajuan yang jauh jika 
dibandingkan dengan negara-negara Islam yang telah mengalami kemajuan tersebut. Sesungguhnya jawaban klasik terhadap persoalan ini adalah bahwa pendidikan menjadi solusi dari ketertinggalan sumberdaya manusia di berbagai negara Muslim ini. Tetapi meski telah menjadi jawaban klasik, pergerakan ke arah penyelesaian masalah ini juga tidak kunjung mengalami peningkatan. Jika kita percaya kepada pemeringkatan universitas-universitas dunia sebagai salah satu tolok ukur bagi kualitas pendidikan tinggi, maka fakta yang kita dapatkan tidak akan jauh berbeda dengan konteks sumberdaya manusia di atas. Misalnya, Q.S. World University Ranking, dalam rilis peringkat universitas dunia tahun 2014 menyebutkan bahwa peringkat-peringkat tertinggi universitas dunia masih dikuasai oleh negara-negara Amerika Serikt (AS) dan Eropa.

Sebagai contoh, peringkat pertama (1) hingga lima puluh (50) universitas terkemuka di dunia adalah universitas-universitas yang berada di negara-negara seperti AS, Inggris, Singapura, Kanada, Australia, Belanda, Jepang dan Tiongkok. Pada peringkat selanjutnya, yakni lima puluh satu (51) hingga seratus (100), belum juga terdapat universitas-universitas dari negara Muslim yang menempati peringkat tersebut. Universitas dari negara Muslim yang menempati peringkat tertinggi adalah Universiti Malaya, Malaysia, yang berada pada peringkat 151 kampus terkemuka dunia. Universitas negara Muslim yang memiliki peringkat kedua setelah Universiti Malaya adalah King Fahd University of Petroleum and Minerals, Saudi Arabia yang bertengger pada posisi 225, disusul King Saud University, Saudi Arabia pada posisi 249. Di bawah universitas-universitas ini, terdapat nama Universiti Kebangsaan Malaysia (UKM) yang berada pada peringkat 259. Sementara universitas-universitas di negara-negara Muslim lain seperti Indonesia, Turki, Iran, Pakistan, Bangladesh, Mesir, Qatar, Kuwait, Lebanon, Iraq, Syiria dan Maroko, misalnya, berada pada peringkat di atas 300, atau bahkan sama sekali tidak menempati posisi apapun dalam pemeringkatan ini. ${ }^{4}$

Memang, pemeringkatan seperti ini sangat subjektif dan bisa saja bersifat politis. Tetapi, kenyataan semacam ini bisa juga diambil sebagai sebuah refleksi bahwa memang kualitas sumberdaya manusia yang kemudian berpengaruh pada peringkat universitas-universitas di negara-negara Muslim. Dengan sendirinya, kenyataan ini bisa ditafsirkan sebagai kekurangsiapan negara Muslim dalam menghadapi persaingan global.

4 Lihat http://www.topuniversities.com/university-rankings/world-university-rankings/ 2014\# sorting $=$ rank + region $=+$ country $=+$ faculty $=+$ stars $=$ false + search $=$, diakses pada tanggal 25 Oktober 2014. 
Situasi ini, lalu diperparah dengan kondisi kemiskinan di sejumlah negara Muslim. Zubair Mughal, Chief Executive Officer, al-Huda Center of Islamic Banking and Economics, Pakistan menyebutkan, jumlah kemiskinan di negara-negara Muslim berkembang sangat pesat. Setengah dari total angka kemiskinan global adalah negaranegara Muslim. Lebih lanjut, Mughal menyebutkan faktor-faktor yang menyebabkan peningkatan angka kemiskinan di negara-negara Muslim ini, yakni rendahnya tingkat pendidikan, tingginya angka pengangguran, dan instabilitas politik. ${ }^{5}$

Senada dengan fakta ini, Majid Semeti mengutip sebuah data yang menyebutkan bahwa sebagian besar penduduk negara-negara Muslim hidup dengan pendapatan di bawah satu dolar setiap hari. Dengan parameter itu, maka jumlah penduduk berpendapatan sangat rendah di Uganda adalah 82,2 persen (1996), di Mali 72,8 persen (1994), Nigeria 70,2 persen (1997), Niger 61,4 persen (1995), Burkina Faso 61,2 (1994) persen, Gambia 59,3 persen (1998), Sierra Leone 57,0 persen (1989), dan Bangladesh 36,0 (2000). Selain itu, menurut laporan Bank Dunia tahun 2000 yang dikutip oleh Semeti, dari 57 negara Muslim, 29 negara merupakan negara dengan pendapatan rendah, 16 negara masuk ke dalam kategori negara berpendapatan menengah, dan hanya 8 negara yang memiliki pendapatan tinggi. ${ }^{6}$

\section{Radikalisme Agama}

Selain problem kemiskinan dan ketertinggalan seperti di atas, dunia Islam saat ini juga sedang menghadapi persoalan yang berkaitan dengan meningkatnya radikalisme agama. Tentu saja, Islam sangat sulit menghindarkan diri dari isu radikalisme agama ini, termasuk Muhammadiyah. Terlebih sejumlah penelitian maupun fakta empiris di lapangan seringkali melakukan asosiasi Muhammadiyah dengan problem radikalisme agama. Dihubungkannya Muhammadiyah dengan radikalisme keagamaan ini terjadi lantaran sejumlah pelaku kekerasan yang mengatasnamakan Islam ditengarai pernah memiliki hubungan emosional dengan Muhammadiyah. Meski penelitian lebih lanjut tentang hubungan ini perlu dilakukan, namun asosiasi itu sering tidak bisa dihindari. Padahal radikalisme agama, bukanlah sebuah isu yang eksklusif Islam, dan apalagi Muhammadiyah, mengingat semua agama memiliki potensi radikalisme yang sama, ${ }^{7}$ tak terkecuali radikalisme agama di kalangan umat Katolik yang merupakan agama mayoritas di AS.

5 Lihat "Poverty in Muslim World is Rapidly Increasing: Zubair Mughal", http://www.alhudacibe.com/
imhd/news22.php, diakses pada tanggal 25 Oktober 2014. 
Maka, perang yang dikumandangkan oleh Pemerintahan George W. Bush melawan brbagai kelompok Islam garis keras yang sering dituduh sebagai teroris, pada dasarnya adalah perang antara dua kutub fundamentalisme. Terorisme yang selalu dikaitkan dengan Islam, terlepas benar atau tidak, secara teoretik dilakukan oleh aliran Islam fundamentalis. Kelompok Islam fundamentalis dengan sikap keagamaannya yang sangat kaku, senantiasa menutup ruang dialog, tidak hanya dengan kelompok di luar Islam, tetapi juga dengan kelompok dalam Islam sendiri yang tidak sejalan dengan prinsip-prinsip yang mereka anut.

Adalah dari prinsip beragama yang teramat kaku ini, kelompok Islam fundamentalis kemudian mengambil sikap anti-Barat dan utamanya anti AS yang kemudian diwujudkan dalam berbagai tindakan kekerasan. Terhadap situasi seperti ini, semestinya kita tidak selalu terfokus pada analisa politik. Karena di luar soal politik, perang melawan terorisme yang dilakukan oleh AS adalah cermin dari sikap fundamentalime agama. Fundamentalisme keagamaan itu juga kemudian mewujud dalam berbagai kebijakannya yang tidak populer di mata dunia. James Risen secara gamblang memaparkan fakta-fakta tentang fundamentalisme sikap Bush. Misalnya, bagaimana Bush dengan dukungan CIA memanipulasi kebenaran seputar fakta tentang pemilikan senjata pemusnah oleh Irak. James Risen menjelaskan dengan fakta yang meyakinkan bahwa apa yang dituduhkan oleh AS kepada Irak sebagai negara pemilik senjata pemusnah massal, sama sekali tidak benar, karena proyek nuklir Irak telah dihancurkan lebih dari satu dekade silam, pada saat AS di bawah kepemimpinan Bush senior melakukan invasi terhadap Irak. ${ }^{8}$

Kerasnya sikap-sikap politik Bush sebenarnya tidak bisa dipisahkan dari strategi fundamentalismenya di tengah menguatnya gerakan fundamentalisme Kristen di AS belakangan ini. Di luar anggapan umum yang melihat AS sebagai negara sekular dan tidak religius, AS adalah negara yang sangat religius. Sebuah laporan The Week pada edisi Juli 2004 menyebut bahwa orang AS ternyata sangat religius. Lebih dari 90 persen orang AS, tulis laporan itu, percaya pada Tuhan dan 75 persen menyatakan memiliki keterlibatan khusus dalam aliran-aliran keagamaan. Jumlah kaum fundamentalis Kristen di AS, diperkirakan sebanding

6 Majid Semeti, A Spatial Analysis of Poverty in Arab and Muslim Countries. Artikel ini bisa didapatkan di alamat: http://www.uned.es/emma/sameti.pdf

7 Karen Armstrong, Berperang Demi Tuhan (Bandung: Mizan, 2001).

8 Lihat James Risen, State of War: The Secret History of the CIA and the Bush Administration (New York: Free Press, 2006). 
dengan jumlah penganut Islam di Indonesia. Kenyataan ini tidak hanya mengejutkan bagi orang luar, tetapi juga menjadikan sejumlah pemimpin agama di AS sendiri khawatir tentang pengaruhnya pada kehidupan politik di AS.

Fakta-faktanya memang demikian. Menguatnya pengikut dan massa fundamentalisme Kristen telah menyentakkan kesadaran para politisi di AS untuk menjadikannya sebagai basis dukungan politik. Sebagai catatan, sebuah peristiwa yang terjadi pada tahun 1964 bisa menjadi salah satu bukti dari gejala ini. Pada tahun itu, menyusul kekalahan Barry Goldwater dalam pemilihan presiden, sekelompok kecil pendukung Partai Republik yang dipimpin oleh Paul Weyrich memutuskan untuk mengubah dan memperluas basis tradisional Republik. Tidak lain, kelompok fundamentalis Kristen, gereja Pentakosta dan Kharismatik yang menjadi sasaran mereka. Pada 1979, sekelompok pengikut Kristen fundamentalis menggabungkan diri dengan seorang missionaris Kristen, Jerry Fallwel untuk mendirikan sebuah organisasi yang dikenal dengan Moral Majority. Kelompok ini mengusung motto: Get them saved, get them baptised, and get them registered. Prinsip ini mengandung konsekuensi religius dan politis pada saat bersamaan, karena mereka tidak hanya berambisi menjadikan orang sebagai bagian dari komunitas religius mereka, tetapi menjadikan mereka juga sebagai aset politik.

Aroma politik itu kian kentara ketika, menyusul aksi-aksi di atas, ribuan pendeta Kristen dari Southern Baptist Convention - sebuah komunitas denominasi Protestan terbesar di AS dengan 42.000 gereja dan 16 juta anggota - mendapatkan pelatihan politik. Tampaknya, pada poin inilah telah terjadi aliansi strategis antara kelompok gereja dan politisi. Pada gilirannya, aliansi strategis ini yang kemudian menumbuhkan kesadaran kalangan fundamentalis Kristen AS untuk melakukan integrasi nilai-nilai Kristiani dalam konteks kenegaraan. Mereka juga menilai bahwa Yesus menjadi contoh terbaik dari hal ini. Jan Rocha (2004) menyebut bahwa Yesus adalah seorang tawanan politik, sehingga ia mati muda di tiang salib dan bukan seorang yang mati tua di tempat tidur. Sehingga tujuan politik akhir dari kelompok ini adalah menjadikan AS sebagai negara Kristen yang mengadopsi prinsip-prinsip dalam Bibel sebagai konstitusi negara. Berbagai agenda khusus yang mereka perjuangkan adalah menghapus undang-undang yang memperbolehkan aborsi, pencegahan homoseksual, mengajarkan prinsip kreasionisme - prinsip bahwa alam ini diciptakan dari ketiadaan yang merupakan salah satu doktrin terpenting dalam Kristen ortodoks - di sekolah-sekolah dan memperkenalkan ibadah di banyak sekolah. 
Penekanan strategi awal yang dilakukan oleh kelompok ini adalah mendorong orang untuk memilih Partai Republik. Pada 1976, Jimmy Carter dari Partai Demokrat, yang sebenarnya adalah seorang evangelis sejati, berhasil memenangi 66 persen suara dari aliran baptis kulit putih. Tetapi sebuah perubahan dramatis terjadi empat tahun kemudian, ketika 64 persen dari pemilihnya itu justru beralih memilih Ronald Reagen. Menariknya, beralihnya pendukung Carter ke Reagen dimotivasi oleh simbol-simbol keagamaan, karena Reagen menyatakan secara terbuka bahwa Bibel merupakan jawaban dari semua persoalan keduniaan. Dalam konteks politik Amerika kontemporer, kelompok konservatif Kristen saat ini menguasai mayoritas kursi komite negara bagian dari Partai Republik. Target utama kelompok Kristen Sayap Kanan, jika Bush kembali terpilih, adalah menguasai Mahkamah Agung (Supreme Court). Bahwa dua atau tiga hakim yang berasal dari kalangan liberal, segera digantikan oleh hakim dari kelompok ultrakonservatif.

Di sisi lain, ambisi kelompok Kristen Sayap Kanan ini juga bisa termanifestasi dalam berbagai aksi kekerasan. Vanessa Baird menengarai bahwa Kristen Sayap Kanan telah menjadi penyebab lahirnya sejumlah kekerasan endemik dalam masyarakat Amerika. ${ }^{9}$ Mereka menolak reformasi hukum tentang senjata, dan mendukung hukuman mati, bahkan menurut mereka, kelompok imigran harus dihentikan dengan cara yang paling keras sekalipun. Adalah benar, lanjut Baird, bahwa mereka tidak pernah menyebut semua itu dalam berbagai khutbah publik, tetapi mereka mendasarkan semua prinsip itu pada xenophobia dan teologi wahyu mereka yang agresif. Ini karena, tulis Karen Armstrong, kitab suci mereka dalam banyak hal menyatakan tentang tindakan kekerasan, sehingga bagi kalangan fundamentalis begitu mudah untuk menemukan teks-teks keagamaan yang memberikan label persetujuan ilahiyah pada tindakan-tindakan brutal. ${ }^{10}$

Peluang kelompok fundamentalis Kristen untuk menguasai negara memang semakin terbuka dengan terpilihnya Bush untuk kedua kalinya. Terlebih Bush sendiri memang terlihat sangat fundamentalis. Konfidensi Bush untuk melakukan berbagai tindakan sepihak melawan terorisme global juga tidak lepas dari prinsip fundamentalis yang selama ini dia anut. "Tuhan memerintahkanku untuk menghancurkan al-Qaedah dan aku benar-benar memburunya. Tuhan jugalah

\footnotetext{
9 Vanessa Baird, "In the Name of GOD," New Internationalist Magazine, Issue 370 (2004), bisa diakses di http://newint.org/features/2004/08/01/keynote/

10 Karen Amstrong, Ibid.,
} 
yang kemudian membisikkan kepadaku untuk menyingkirkan Saddam Hussein, suatu hal yang juga sudah aku lakukan," kata Bush suatu ketika. "Kepatuhan" Bush pada kelompok fundamentalis juga tidak bisa diingkari ketika pada tahun 2002, ketika ia meminta Ariel Sharon untuk menarik tentaranya dari Jenin. Pada saat itulah ia menerima 100.000 surat elektronik yang berisi kemarahan kaum fundamentalis Kristen, dan sejak saat itu Bush tidak lagi pernah mengulangi permintaan itu.

Diperkirakan dari tahun ke tahun dominasi kelompok Kristen Sayap Kanan akan semakin kuat dan proliferal. Tujuan akhir mereka yang ingin menjadikan Amerika sebagai negara Kristen, dengan sendirinya akan menggeser prinsip sekularisme politik yang ingin memisahkan negara dan gereja. Ini berarti bahwa apa yang pernah terjadi pada abad pertengahan di mana gereja mendominasi seluruh dimensi kehidupan negara, akan kembali terulang. Ironisnya, ini terjadi di Amerika, sebuah negara yang dari luar justru nampak sebagai anti-agama dan fundamentalisme agama.

\section{Peran Muhammadiyah}

Di tengah situasi seperti ini, maka menjadi penting untuk menengok peran apa yang bisa dimainkan oleh Muhammadiyah. Setidaknya, terdapat tiga peran yang bisa ditawarkan oleh Muhammadiyah dalam menghadapi situasi kontemporer dunia Islam ini, yaitu: a) sebagai model moderatisme Islam; b) sebagai model bagi peningkatan kualitas pendidikan Islam; dan c) model dan sarana bagi peningkatan ekonomi umat.

\section{Model Moderatisme Islam}

Meski sejumlah studi sering mengaitkan Islam dan radikalisme, di satu sisi; dan lahirnya dua kelompok yang bertentangan (lahirnya kelompok yang dianggap liberal dan kelompok yang dianggap konservatif), di sisi yang lain; posisi Muhammadiyah sebagai gerakan Islam moderat sebenarnya tidak tergoyahkan. Sebelum berdiskusi lebih jauh tentang poin ini, ada baiknya istilah moderat di sini didudukkan lebih awal. Istilah Islam moderat ternyata memiliki makna yang berbeda bagi kalangan yang berbeda. Umat Islam Indonesia, memaknai moderatisme sebagai posisi ideal karena ia bermakna sebuah posisi tengahan yang menghindari dua kutub ekstrem. Setidaknya itulah yang tergambarkan dari

11 Vanessa Baird, "In the Name of GOD," New Internationalist Magazine, Ibid., 
penjelasan almarhum Kuntowijoyo. ${ }^{12}$ Ini setidaknya berbeda dengan konsep Islam moderat dalam pemahaman sejumlah kalangan di Barat yang cenderung menyamakan Islam moderat dengan apa yang di Indonesia lebih banyak dikenal sebagai Islam liberal. ${ }^{13}$

Sebagai sebuah agama, Islam pada dasarnya menempatkan moderatisme sebagai sebuah nilai. Perkataan khairu al-umuri awsathuha (bahwa perkara yang paling baik adalah yang berada di tengah-tengah) menyiratkan prinsip Islam yang menekankan pada pentingnya bersikap moderat (tengah-tengah, dan bukan setengah-setengah) dalam setiap persoalan. Jika hendak dijabarkan lebih lanjut, maka moderatisme Islam ini harus diwujudkan baik dalam tindakan, perkataan maupun pemikiran. Muhammadiyah adalah gerakan Islam yang menjunjung tinggi moderatisme dalam bertindak dan berfikir. Bukti moderatisme Muhammadiyah adalah bentuk penafsiran agama yang rasional dan modern, berbasis pada teks di satu sisi, tetapi juga menjadikan realitas sebagai elemen penting bagi penafsiran teks itu. Tegasnya, Muhammadiyah memadukan antara pendekatan tekstual dan kontekstual dalam penafsiran agama. Dalam konteks dakwah Islam, kredo amar ma'ruf nahi munkar, sebenarnya menyiratkan prinsip moderatisme. Kembali ke Kuntowijoyo, amar ma'ruf diartikan sebagai humanisasi, sementara nahi munkar disepadankan dengan liberasi. Atau dalam rumusan yang lain, moderatisme Muhammadiyah bisa diwujudkan dalam kredo "amal ilmiah dan ilmu amaliah".

Mengembangkan moderatisme Islam seperti model Muhammadiyah ini menjadi penting di tengah menguatnya arus radikalisme agama belakangan ini. Sehingga, moderatisme akan menjadi jalan bagi pemahaman Islam yang lebih realistis. Pemahaman Islam yang realistis pada gilirannya akan menjadi landasan bagi kerja-kerja membangun peradaban umat Islam, serta menjadi sarana bagi proses-proses pencerahan yang senantiasa mengalami dinamika dari zaman ke zaman.

\section{Model Pendidikan Unggul}

Kemampuan Muhammadiyah dalam mengelola pendidikan memang sama sekali tidak diragukan. Demikian juga jumlah pendidikan yang dimiliki oleh Muhammadiyah juga teramat melimpah. Dalam kaitan ini, maka Muhammadiyah

Kuntowijoyo, Identitas Politik Umat Islam (Bandung: Mizan, 1997).

13 Lihat misalnya, Graham E Fuller, The Future of Political Islam (New York: Palgrave Macmillan, 2003). 
telah memainkan peran yang sangat penting dalam upaya pencerdasan bangsa. Dengan kata lain, dalam bidang pendidikan, sebenarnya kontribusi Muhammadiyah dalam membantu negara untuk mencerdaskan bangsa teramat besar. Hanya saja, kebanggaan itu harus segera diimbangi dengan refleksi akan kualitas pendidikan Muhammadiyah di tengah persaingan yang sangat ketat dewasa ini.

Memang benar, bahwa pendidikan Muhammadiyah telah banyak menawarkan pendidikan unggul bagi masyarakat Indonesia dalam konteks lokal. Tetapi jika merujuk pada fakta tentang peringkat universitas dunia sebagaimana dikutip pada bagian terdahulu, maka akan segera terasa bahwa pusat-pusat pendidikan tinggi yang dimiliki oleh Muhammadiyah belum banyak yang mampu berbicara pada kancah global. Maka, dengan memperhatikan dua isu dunia Islam kontemporer sebagaimana disinggung di atas, Muhammadiyah harus memikirkan terobosan-terobosan peningkatan kualitas pendidikan dalam upaya menjadi model pendidikan unggul dalam setiap konteks zaman. Jika diperhatikan, pembaruan model pendidikan sebagaimana dicontohkan oleh Kiai Dahlan seabad yang lalu, merupakan bukti keselarasan pendidikan dengan kebutuhan zaman. Kini zaman telah berubah, sehingga semangat keselarasan dengan zaman dalam mengelola pendidikan Muhammadiyah tetap menjadi semangat utama. Model seperti inilah yang secara sederhana bisa ditawarkan sebagai sebuah model dalam menghadapi isu-isu Islam kontemporer.

Namun harus pula digarisbawahi bahwa lembaga-lembaga pendidikan Muhammadiyah seringkali terjebak pada egoisme sektoral. Apa yang dimaksudkan dengan egoisme sektoral atau individualisme lembaga pendidikan Muhammadiyah adalah seringkali sinergi dan kerjasama antarlembaga pendidikan tidak dapat dilakukan lantaran masing-masing lembaga seringkali berfikir dalam kerangka yang parsial dan bukan sistemik. Sebagai contoh, disparitas kualitas antara satu sekolah Muhammadiyah dengan lainnya kadang-kadang sangat tajam. Sayangnya, kerjasama antarberbagi lembaga pendidikan itu tidak dilakukan atas dasar bahwa masing-masing lembaga pendidikan memiliki independensi.

Contoh lain adalah, adanya lempar tanggung jawab antar berbagai organ dalam Muhammadiyah, ketika menyangkut penanganan hal-hal yang bersifat mendesak. Sebuah sekolah yang dikelola oleh 'Aisyiyah di sebuah tempat, misalnya, mengalami persoalan yang mendasar tentang pengelolaan sekolah. Ketika diajukan penyelesaian terhadap masalah sekolah ini, Muhammadiyah 
setempat menolak melakukan penyelesaian atas dasar bahwa sekolah tersebut adalah milik Aisyiyah, dan bukan Muhammadiyah. Padahal, bukankah Muhammadiyah dan 'Aisyiyah berada dalam satu poros dakwah dan harusnya bahu-membahu? Benar, bahwa hal-hal seperti bersifat sangat kasuistik. Tetapi, jika tidak dicarikan formula penyelesaian, maka ini akan menjadi persoalan yang menghambat kemajuan pendidikan Muhammadiyah dan terlebih usaha menjadikan Muhammadiyah sebagai model pendidikan unggul.

\section{Model Peningkatan Ekonomi Umat}

Selain dari dua hal di atas, berfikir tentang metode-metode alternatif peningkatan kesejahteraan umat menjadi sangat penting. Dalam kaitan ini, sekali lagi, Muhammadiyah sebenarnya bisa tampil sebagai model pemberdayaan atau peningkatan ekonomi umat. Sebagaimana gerakan Islam lainnya, Muhammadiyah juga meyakini bahwa zakat merupakan suatu institusi keuangan umat yang berpotensi besar membuat perubahan dalam kehidupan ekonomi umat. Secara sporadis, berbagai organ dalam Muhammadiyah telah melakukan penghimpunan penghimpunan potensi ekonomi ini sebagai sarana peningkatan kualitas ekonomi masyarakat. Tetapi sekali lagi, sebagaimana konteks yang disebutkan di atas, pola pikir sektoral atau individualisme kelembagaan yang menjangkit masing-masing elemen dalam Muhammadiyah, seringkali menjadi halangan serius bagi peningkatan kualitas ekonomi umat.

Ada satu mata rantai yang sulit dipecahkan dalam dinamika sosial umat Islam belakangan ini. Sebagaimana disebutkan dalam diskusi di atas, salah satu sebab bagi ketertinggalan dalam bidang pendidikan dan ekonomi adalah kemiskinan. Dengan sendirinya, tidak ada cara lain untuk meningkatkan kualitas ekonomi umat; atau membawa masyarakat marginal ke tengah gelanggang kehidupan sosial dan ekonomi selain pendidikan. Tetapi di sinilah problemnya. Sementara pendidikan diyakini sebagai sarana itu, kemampuan kelompok masyarakat bawah atau marginal dalam mengakses pendidikan juga menjadi persoalan tersendiri karena secara perlahan namun pasti pendidikan telah menjadi aktivitas industrial. Di sinilah mata rantai kemiskinan umat itu sulit untuk diputuskan.

Maka, mengaca kepada persoalan ini, Muhammadiyah sudah sepatutnya mampu tampil menjadi pelopor peningkatan kualitas ekonomi umat melalui penyediaan pendidikan bagi masyarakat bawah. Di tengah industri pendidikan 
yang menggejala, dengan kekuatan ekonominya yang sekarang ini semakin kokoh, Muhammadiyah harus senantiasa mengambil peran-peran kepeloporan dalam peningkatan kesejahteraan umat melalui pendidikan. Muhammadiyah sesungguhnya telah melakukan semua itu. Misalnya, dengan banyaknya panti asuhan Muhammadiyah di berbagai pelosok tanah air. Secara fisik, keberadaan panti asuhan-panti asuhan Muhammadiyah itu telah mampu menciptakan mobilisasi sosial baik utamanya horizontal dalam kehidupan masyarakat. Namun, upaya peningkatan dalam tataran yang non-fisik juga harus dilakukan. Tegasnya, panti asuhan-panti asuhan Muhammadiyah, sudah saatnya untuk berfikir tentang penataan mental peserta didik. Karena jika pemenuhan kebutuhan materiil untuk peserta didik di panti asuhan-panti asuhan Muhammadiyah tidak dibarengi dengan penataan mental, maka peningkatan kualitas ekonomi umat akan sulit untuk diraih.

\section{Penutup}

Sebagai penutup dari refleksi intelektual di atas adalah, Muhammadiyah sebagai organisasi Islam dan kemanusiaan terbesar di dunia, memiliki formulasi nilai-nilai kebajikan yang sangat baik dan potensial dalam rangka menjawab segala tantangan kontemporer. Kendati demikian, formulasi tersebut harus senantiasa dikembangkan secara terus-menerus seiring dengan perkembangan zaman. Secara umum sebenarnya, berbagai nilai kebajikan yang bersifat solutif dan senantiasa memperbarui diri, kerap disebut dengan istilah Islam berkemajuan (progresif).

Hal-hal esensial mengenai pemikiran progresif Muhammadiyah, antara lain adalah afirmasi terhadap paham moderatisme Islam. Makna moderat yang paling fundamental bagi Muhammadiyah adalah adanya kesatuan antara iman dan amal saleh. Sementara itu menurut catatan sejarah, dimensi moderatisme Muhammadiyah ini telah dipraktikkan oleh para pemimpin generasi awal di bidang pendidikan Islam. Oleh karena itu, secara etis sesungguhnya kita bisa mengambil pelajaran dari sejarah tersebut, agar supaya menjadi pioner pembaruan pendidikan Islam di zaman yang lebih maju ini.

Seiring dengan perumusan agenda pembaruan pendidikan Islam di era kontemporer, secara integratif, kita perlu meningkatkan akselerasi pengentasan kemiskinan dan membangun basis-basis ekonomi umat. Ikhtiar ini tidak lain adalah karena untuk menghapus segala masalah mengenai ketidakmampuan 
mengakses pendidikan yang berkualitas, oleh sebab kemiskinan yang mendera. Dus, inilah yang dimaksud dengan moderasi Islam versi Muhammadiyah, di satu sisi memberikan perhatian pada revolusi mental (iman) bagi umat melalui pendidikan Islam, di sisi lain juga bekerja keras dalam rangka pemberdayaan dan pembangunan kemandirian ekonomi umat. Bila landasan filosofis Muhammadiyah sedemikian maju, pertanyaan berikutnya adalah, apakah tidak cukup penting untuk mendakwahkan hal tersebut di hadapan publik internasional? Penting sebagai refleksi kita bersama bahwa, Muhammadiyah tidak lagi bertanggungjawab untuk menyelesaikan problematika umat di daerah Yogyakarta semata, bahkan hanya di Indonesia, tetapi juga di seluruh dunia.[]

\section{Bibliografi}

Armstrong, Karen, Berperang Demi Tuhan, Bandung: Mizan, 2001.

Baird, Vanessa, "In the Name of GOD," New Internationalist Magazine, Issue 370 (2004), bisa diakses di http://newint.org/features/2004/08/01/keynote/ Farouki, Suha Taji dan Basheer M Nafi, Islamic Thought in the Twentieth Century, London and New York: I.B.Tauris, 2004.

Fuller, Graham E., The Future of Political Islam, New York: Palgrave Macmillan, 2003.

Kuntowijoyo, Identitas Politik Umat Islam, Bandung: Mizan, 1997.

Nasution, Harun, Pembaharuan dalam Islam: Sejarah Gerakan dan Pemikiran, Jakarta: Penerbit Bulan Bintang, 1975.

Risen, James, State of War: The Secret History of the CIA and the Bush Administration, New York: Free Press, 2006.

Semeti, Majid, A Spatial Analysis of Poverty in Arab and Muslim Countries. Artikel ini bisa didapatkan di alamat: http://www.uned.es/emma/sameti.pdf al-Surjani, Raghib, Qissatu al-Andalusi: Min al-Fathi ila al-Suquth, Mesir: Mu'assasah al-Iqra' li al-Tansyir wa al-Tauzi', 2011.

http://www.topuniversities.com/university-rankings/world-university-rankings/ 2014\# sorting $=$ rank + region $=+$ country $=+$ faculty $=+$ stars $=$ false + search $=$, diakses pada tanggal 25 Oktober 2014.

"Poverty in Muslim World is Rapidly Increasing: Zubair Mughal," http:// www.alhudacibe.com/imhd/news22.php, diakses pada tanggal 25 Oktober 2014. 